\title{
Basal ice microbiology at the margin of the Greenland ice sheet
}

\author{
Jacob C. YDE, ${ }^{1,2}$ Kai W. FINSTER, ${ }^{3}$ Rob RAISWELL, ${ }^{4}$ Jørgen P. STEFFENSEN, ${ }^{5}$ \\ Jan HEINEMEIER, ${ }^{6}$ Jesper OLSEN, ${ }^{7}$ Haraldur P. GUNNLAUGSSON, ${ }^{8}$ \\ Ole B. NIELSEN ${ }^{9}$ \\ ${ }^{1}$ Center for Geomicrobiology, Aarhus University, Ny Munkegade building 1535, DK-8000 Aarhus, Denmark \\ E-mail: yde@phys.au.dk \\ ${ }^{2}$ Bjerknes Centre for Climate Research, University of Bergen, Allégaten 55, NO-5007 Bergen, Norway \\ ${ }^{3}$ Department of Biological Sciences, Aarhus University, Ny Munkegade 114, DK-8000 Aarhus, Denmark \\ ${ }^{4}$ School of Earth and Environment, University of Leeds, Leeds LS2 9JT, UK \\ ${ }^{5}$ Centre for Ice and Climate, University of Copenhagen, Juliane Maries Vej 30, DK-2100 Copenhagen, Denmark \\ ${ }^{6} \mathrm{AMS}{ }^{14} \mathrm{C}$ Dating Centre, Department of Physics and Astronomy, Aarhus University, Ny Munkegade 120, \\ DK-8000 Aarhus, Denmark \\ ${ }^{7}$ 14CHRONO Centre for Climate, the Environment and Chronology, School of Geography, Archaeology and Palaeoecology, \\ Queen's University, Belfast BT7 1NN, UK \\ ${ }^{8}$ Department of Physics and Astronomy, Aarhus University, Ny Munkegade 120, DK-8000 Aarhus, Denmark \\ ${ }^{9}$ Department of Earth Sciences, Aarhus University, C.F. Møllers Allé 2, DK-8000 Aarhus, Denmark
}

\begin{abstract}
Basal ice at the margin of the Greenland ice sheet was studied with respect to its physical characteristics and microbiological community. The basal ice contained high concentrations of dissolved ferrous Fe and must therefore be anoxic. Oxygen consumption experiments indicate that $50 \%$ of the oxidation was due to biological activity while the rest could be attributed to chemical processes, most likely weathering reactions with ferrous Fe. At least six different Fe-containing mineral sources were detected in basal ice together with potential bioavailable Fe nanoparticles. An active denitrifier population was identified due to formation of ${ }^{30} \mathrm{~N}$-dinitrogen gas after amendment of anoxic sediment slurries with ${ }^{15} \mathrm{~N}-\mathrm{NO}_{3}{ }^{-}$. Sulfate reduction could not be detected. The solid ice facies contained an abundant $\left(\sim 10^{8}\right.$ cells $\left.\mathrm{cm}^{-3}\right)$ and complex microbial community that harbored representatives of at least eight major phyla within the domain Bacteria. The clone library was dominated by members of the $\beta$ subdivision of proteobacteria of which the largest proportion was affiliated to the genus Rhodoferax that comprises facultative aerobic iron reducers. The second most abundant phylum was Bacteroidetes. The solid ice facies had many physical similarities with the overlying debris-rich banded ice facies, indicating that they formed by similar subglacial processes and harbor similar microbial communities. This study extends our knowledge of life in subglacial environments such as beneath ice sheets. GenBank accession numbers: HM439882-HM439950; HQ144215-HQ144221.
\end{abstract}

\section{INTRODUCTION}

Basal ice is part of the subglacial ecosystem, which comprises the basal ice zone, the subglacial sediments and subglacial water (e.g. Hodson and others, 2008). It is defined as ice that has acquired distinctive physical and/or chemical characteristics as a result of processes operating at or near the bed of glaciers (Knight, 1997; Hubbard and others, 2009). These processes are reflected in the genesis and postformational alteration of distinct basal ice types (referred to as basal ice facies) that can be classified according to physical ice properties such as thickness, debris concentration and texture, and bubble concentration and size (Hubbard and others, 2009). In addition, analytical techniques (e.g. ice crystallography, electrical conductivity measurements, co-isotope analysis of $\delta^{18} \mathrm{O}$ and $\delta \mathrm{D}$, and gas composition of $\mathrm{CO}_{2}, \mathrm{CH}_{4}$ and $\mathrm{O}_{2}$ in bubbles) have been used to further describe and differentiate basal ice facies (Knight, 1997).

The previous assumption that subglacial environments are abiotic due to lack of photoenergy and low temperatures has proved to be invalid. It has become more and more evident that microbes not only are present in high numbers in subglacial environments worldwide, but that they actively participate in weathering processes (Tranter and others,
2002, 2005). However, although it is now generally accepted that basal ice provides habitats for metabolizing microorganism communities (Sharp and others, 1999; Skidmore and others, 2000; Sheridan and others, 2003; Miteva and others, 2004; Tung and others, 2006; Yung and others, 2007), an understanding of the role of microorganisms in basal ice facies is only in its infancy.

This paper presents the results of the first study on the microbial community and its potential activities in basal ice at the margin of the Greenland ice sheet (GIS), West Greenland. The focus of our study is on the microbial community in the lowest basal ice facies, referred to as the solid ice facies. We also describe the physical characteristics of the basal ice environment, so that this study may be compared to similar basal ice microbiology studies in order to determine what subglacial processes influence the microbial community structure in various basal ice facies.

\section{STUDY AREA}

The study site $\left(67^{\circ} 08^{\prime} 21^{\prime \prime} \mathrm{N}, 50^{\circ} 02^{\prime} 43^{\prime \prime} \mathrm{W} ; 490 \mathrm{~m}\right.$ a.s.l. $)$ is located between the outlet glaciers Isunguata Sermia and Russell Glacier at the margin of the GIS (Fig. 1). The climate is continental low Arctic and the region is considered to be a 


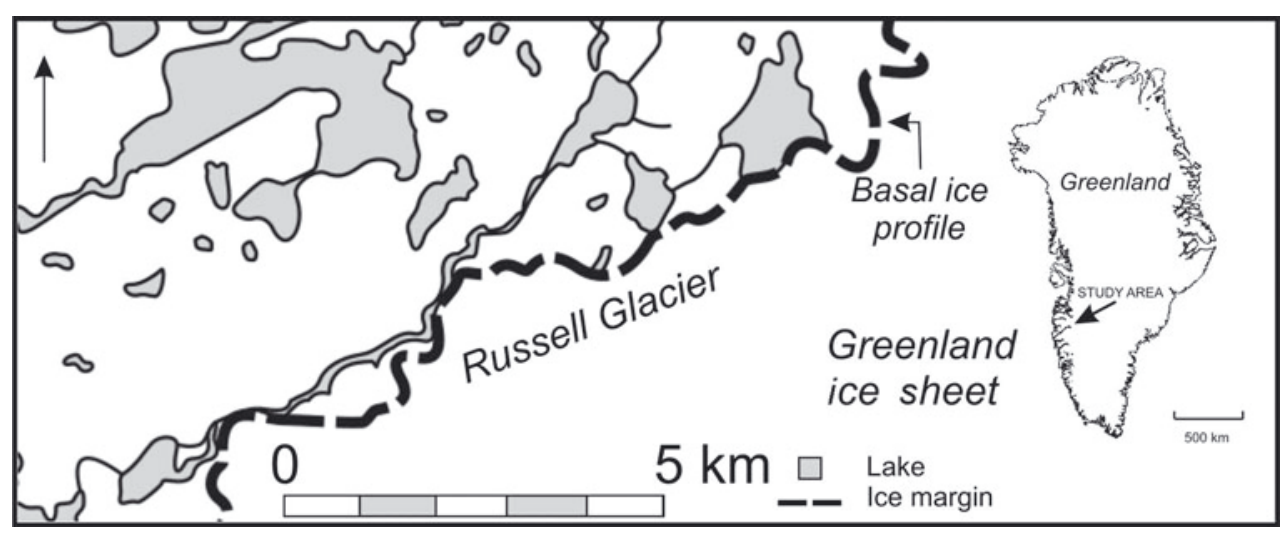

Fig. 1. Location map of the study site at the margin of the GIS, north of Russell Glacier.

polar desert (Hobbs, 1931). The nearest meteorological station is located at the airport of Kangerlussuaq (Søndre Strømfjord), $\sim 31 \mathrm{~km}$ west of the study area. Here the mean annual air temperature and the mean annual precipitation are $-5.7^{\circ} \mathrm{C}$ and $149 \mathrm{~mm}$ (1961-90), respectively (Cappelen, 2009). There is continuous permafrost, with an active layer thickness of $\sim 0.5 \mathrm{~m}$ in peat-covered areas and $>1.0 \mathrm{~m}$ on unvegetated proglacial outwash plains. The geology consists of amphibolite and granulite facies gneisses with deformed and boudinaged basic to intermediate intrusive dykes belonging to the Nagssugtoqidian mobile belt (Escher and others, 1976).

The ice margin at the study site is relatively stable and has maintained its position at least since the Little Ice Age. During the 1968-2002 advance of parts of the ice margin (Knight and others, 2007), the studied section of the ice margin is believed to have increased in ice thickness, whereas since 2002 ice thickness has decreased.

\section{BASAL ICE STRATIGRAPHY}

For this study, a vertical basal ice profile was selected at a location where ice flow was perpendicular to the ice margin and all primary basal ice facies were accessible. There were no signs of deformation, thrusting or duplication in the profile that might unnecessarily complicate the basal ice stratigraphy. Also, the site was not affected by the recent major jökulhlaups that drained an ice-dammed lake located $1 \mathrm{~km}$ westwards (A.J. Russell and others, unpublished information).

The stratigraphic log of the basal ice profile is shown in Figure 2. The profile has a thickness of $1.20 \mathrm{~m}$ and contains ten ice units defined by internal homogeneity.

Englacial ice: The upper unit had an outer appearance characterized by dispersed debris aggregates or 'clots' and was initially assumed to belong to what has previously been described as the clotted or dispersed facies (Knight, 1987, 1989, 1994, 1997; Sugden and others, 1987; Knight and others, 1994, 2002; Waller and others, 2000). However, when the outermost $20 \mathrm{~cm}$ was carefully removed, the unit appeared clean without any visible debris 'clots'. Also, the ice crystals were bubblefree and larger than in other basal ice units. As the unit had no apparent basal ice origin, we refer to this unit as englacial ice.
Banded ice: These units were characterized by intercalating debris-rich and debris-free layers with a general thickness of 1-3 mm. There were no visible bubbles in the debris-rich or debris-poor layers. These units have previously been classified as a subfacies of stratified basal ice (e.g. Waller and others, 2000), but will be ascribed as banded ice according to the non-genetic nomenclature (Hubbard and others, 2009).

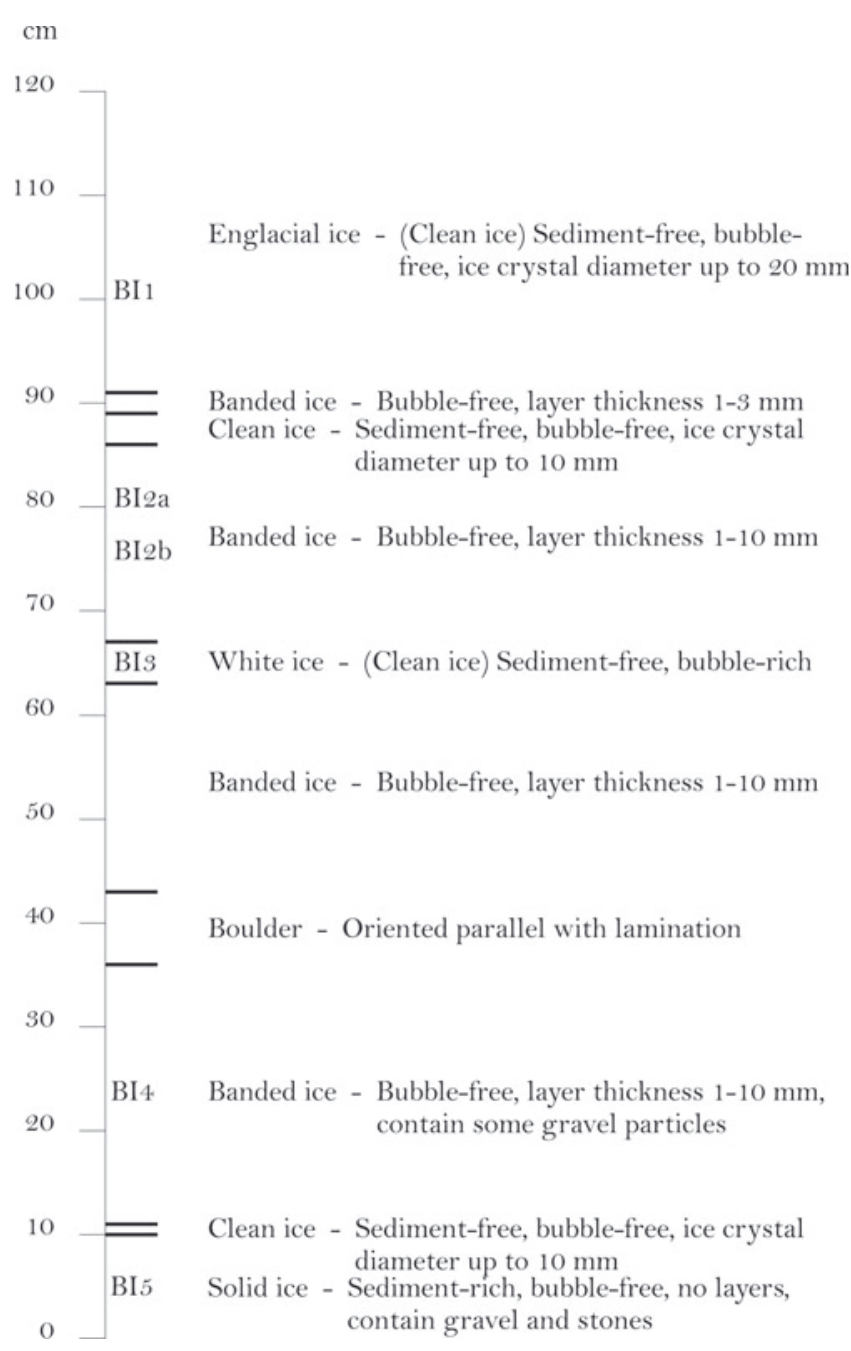

Fig. 2. Stratigraphic log of basal ice facies characteristics in the studied profile. 
Clean ice: Where the ice thickness of the debris-free layers exceeded $10 \mathrm{~mm}$, these layers were defined as separate clean ice facies.

White ice: This layer of clean ice had a white appearance due to a high content of dispersed bubbles. It was genetically classified as névé, i.e. snow compressed into glacier ice. Although névé formation in basal ice has not received much attention, it is in fact a common facies in basal ice (e.g. Knight, 1987).

Boulder: The profile contained a single boulder aligned parallel to the lamination. The boulder did not belong to a single facies, and layers deformed around it.

Solid ice: The lowest facies had no layered structure and no bubbles and appeared as frozen till. This solid ice facies continued beneath the profile, as the contact with bedrock was not accessible because the lower part of the profile was covered by a thick mud apron.

\section{SAMPLING AND ANALYTICAL METHODS}

Sampling was conducted by carefully removing the outermost $20 \mathrm{~cm}$ using an ice axe. Samples were collected in polyethylene soil sample bags and acid-cleaned polypropylene bottles from the englacial facies (BI1), the upper banded facies (BI2a and $\mathrm{BI} 2 \mathrm{~b}$ ), the white ice facies (BI3), the lower banded facies (BI4) and the solid facies (BI5) (Fig. 2). After return to the field station, a part of the sampled material was stored frozen at $-20^{\circ} \mathrm{C}$ for later analysis in the laboratory at Aarhus University, Denmark, including community analysis, and another part was in storage at $5^{\circ} \mathrm{C}$ for studies that were carried out in the field laboratory, including activity measurements.

Debris concentration and particle size of particles $<2 \mathrm{~mm}$ in diameter were measured by evaporation and laser diffraction, respectively. The mineralogical composition was analyzed by X-ray diffraction. The organic carbon and sulfur content was measured using a LECO furnace. Stable oxygen isotope analyses were performed at the Niels Bohr Institute, University of Copenhagen, Denmark, using mass spectrometry with a precision in the $\delta$ value of $\pm 0.1 \%$. Deuterium isotope analyses were performed at the AMS ${ }^{14} \mathrm{C}$ Dating Centre, Aarhus University, with a ratio precision of $\pm 0.5 \%$.

The concentration of $\mathrm{Fe}^{2+}$ in the sediment was measured in duplicates by the ferrozine method (Stookey, 1970). In brief, $0.1 \mathrm{~cm}^{3}$ of sediment was transferred with a tip-cut $1.0 \mathrm{~mL}$ plastic syringe to an Eppendorf tube containing $2 \mathrm{~mL}$ of ferrozine solution, and incubated in the dark at room temperature for $20 \mathrm{~min}$. The absorbance of the red complex was determined spectroscopically at $540 \mathrm{~nm}$, and determined concentrations were compared with standard $\mathrm{Fe}^{2+}$ solutions. Measurements were repeated after 8.5 and 20 hours. Mössbauer spectroscopy was performed on solid ice facies sediment in order to determine the presence of various Fe-containing minerals (Greenwood and Gibb, 1971; Stevens and others, 1998; Bruun and others, 2010). Presence of bioavailable nanoparticulate Fe was determined by treating the solid ice facies sample with an ascorbate solution (FeA), which extracts fresh, nanoparticulate ferrihydrite, and subsequently with a sodium dithionite solution (FeD), which extracts aged, nanoparticulate ferrihydrite and goethite, hematite and lepidocrocite, following the protocol by Raiswell and others (2008b, 2009).

\section{Activity measurements}

Oxygen consumption was followed with a Clark-type microelectrode in triplicate sediment suspensions that were prepared as follows: $1 \mathrm{~cm}^{3}$ of homogenized solid ice sediment was transferred to a $5 \mathrm{~mL}$ Exetainer ${ }^{\circledR}$ with a $1 \mathrm{~mL}$ tip-cut plastic syringe. The Exetainer ${ }^{\mathbb{R}}$ was then filled to the rim with well-aerated water prepared from melted glacier ice. It was closed with a lid without leaving air bubbles and shaken vigorously. Prior to each oxygen measurement the Exetainers ${ }^{\circledR}$ were shaken. The electrode was carefully inserted into the suspension without stirring. It was calibrated with well-aerated ice water and a $1 \mathrm{M}$ ascorbate solution (Revsbech and Jørgensen, 1986). The procedure was repeated at regular intervals. The chemical consumption of oxygen was determined with samples poisoned with $0.3 \mathrm{~mL}$ of $10 \% \mathrm{ZnCl}_{2}$ solution.

Nitrate reduction was determined using a similar set-up to that for oxygen consumption measurements. After depletion of oxygen, ${ }^{15} \mathrm{~N}$-labeled $\mathrm{NO}_{3}{ }^{-}$(final concentration $100 \mu \mathrm{M})$ was added from a sterile stock solution. The Exetainers ${ }^{\circledR}$ were closed and incubated at room temperature in the dark for 28 hours. The incubation was stopped by the addition of $0.3 \mathrm{~mL}$ of $10 \% \mathrm{ZnCl}_{2}$ solution. The formation of ${ }^{30} \mathrm{~N}_{2}$ was determined with a mass spectrometer as described by Nielsen (1991).

Sulfate reduction rates were measured using ${ }^{35} \mathrm{~S}$-labeled $\mathrm{SO}_{4}{ }^{2-}$. One $\mathrm{cm}^{3}$ of sediment was suspended in dithionitereduced ice water in $5 \mathrm{~mL}$ Exetainers ${ }^{\circledR}$ leaving no air bubble. Soil suspensions were amended with $\mathrm{H}_{2}{ }^{35} \mathrm{SO}_{4}$ to a final activity of $100 \mathrm{kBqmL}^{-1}$ sediment suspension and incubated for 42 hours at room temperature and stopped by the addition of $0.3 \mathrm{~mL}$ of $10 \% \mathrm{ZnCl}_{2}$ solution. The formation of sulfide was analyzed by combined chromium and acid distillation as described by Fossing and Jørgensen (1989).

\section{Microbiological studies}

For total cells counts, $1 \mathrm{~cm}^{3}$ of sediment was transferred to pre-weighted $50 \mathrm{~mL}$ centrifuge tubes containing $1.0 \mathrm{~mL}$ $100 \mathrm{~mm}$ sodium pyrophosphate $(\mathrm{pH} 7.5), 7.0 \mathrm{~mL}$ Milli-Q water and $1.0 \mathrm{~mL} 25 \%(\mathrm{v} / \mathrm{v})$ glutaraldehyde, and incubated for $15 \mathrm{~min}$ at $4{ }^{\circ} \mathrm{C}$ followed by weighing and vortexing. The suspension was ultrasonicated for $3 \times 20 \mathrm{~s}$ at $35 \%$ intensity while kept on ice. Milli-Q water was added to a final volume of $40 \mathrm{~mL}$. $40 \mu \mathrm{L}$ was transferred to $10 \mathrm{~mL} 1 \times$ PBS containing $2 \mu \mathrm{L} 10.000 \times$ SYBR Gold using a pipette with a cut-off tip, and incubated in the dark at $4^{\circ} \mathrm{C}$ for $15 \mathrm{~min}$. Five $\mathrm{mL}$ of the stained suspension was filtered onto a $0.2 \mu \mathrm{m}$ pore size black polycarbonate filter (filter chimney diameter $16.23 \mathrm{~mm}$ ), which was subsequently rinsed with $5 \mathrm{~mL}$ Milli-Q water. The filters were mounted with Citifluor containing $1 \mu \mathrm{g} \mathrm{mL}^{-1}$ DAPI and counted at $1000 \times$ magnification (Hansen and others, 2007).

The metabolic potential of the aerobic microbial community was assessed with EcoLog ${ }^{\mathrm{TM}}$ plates. Prior to inoculation, $5 \mathrm{~cm}^{3}$ of sediment was suspended in $20 \mathrm{~mL}$ of a $50 \mathrm{~mm}$ sodium pyrophosphate solution. The suspension was vortexed for $1 \mathrm{~min}$ and the particles were allowed to settle for 1 hour. The EcoLog ${ }^{\text {TM }}$ plates were inoculated with sterile pipettes according to the manufacturer's instructions and incubated at $15^{\circ} \mathrm{C}$ in the dark. The incubations were scored positive when a red color indicating the formation of tetrazolium salt became visible. Plates were only evaluated when the negative control wells remained clear (Hansen and others, 2007). 
Table 1. Bulk and clay mineralogical composition of banded and solid ice facies in basal ice profile at the GIS margin in West Greenland. The proportions are expressed in \% by mass

\begin{tabular}{|c|c|c|c|c|c|c|c|c|}
\hline & Quartz & Plagioclase & K-feldspar & Pyroxene & Amphibole & Pyrite & Mica & Chlorite \\
\hline \multicolumn{9}{|l|}{ Bulk mineralogy } \\
\hline BI2a Banded ice & 12.0 & 46.5 & 4.9 & 5.7 & 30.0 & 1.0 & & \\
\hline BI2b Banded ice & 17.6 & 45.4 & 6.3 & 6.3 & 23.2 & 1.2 & & \\
\hline BI4 Banded ice & 15.8 & 48.0 & 5.5 & 7.2 & 22.1 & 1.5 & & \\
\hline BI5 Solid ice & 17.3 & 46.7 & 4.5 & 4.7 & 25.4 & 1.5 & & \\
\hline BI2a Banded ice & 5.2 & 6.7 & 1.6 & & 7.4 & 1.4 & 72.5 & 5.3 \\
\hline BI2b Banded ice & 5.3 & 5.8 & 1.9 & & 5.4 & 1.0 & 75.6 & 5.0 \\
\hline BI4 Banded ice & 5.2 & 5.7 & 1.4 & & 5.1 & 1.7 & 76.1 & 4.8 \\
\hline BI5 Solid ice & 3.5 & 3.2 & 1.3 & & 5.3 & 0.6 & 82.0 & 4.1 \\
\hline
\end{tabular}

Heterotrophic aerobic bacteria were cultured on R2A (Difco) agar plates. One $\mathrm{cm}^{3}$ of sediment was diluted in $9 \mathrm{~mL}$ of autoclaved ice water and $100 \mu \mathrm{L}$ were streaked on the agar plates (Hansen and others, 2007). Clostridia were enriched in tenfold serial dilution in Clostridium broth (DifCo) under anaerobic conditions (Hansen and others, 2007).

\section{Molecular studies}

DNA was extracted from sediment samples and colonies of cultured microbes using the FastDNA spin kit for soil (Bio 101, CA). The extracted amount of DNA was quantified using a nanodrop device. A clone library was constructed as described by Hansen and others (2007) except that the M13F primer used was 5'-TGT AAA ACG ACG GCC AGT-3' to generate partial sequences. Sequencing was accomplished by the commercial company Macrogen (South Korea).

Sequences were compared to the current database of the rRNA gene sequence from GenBank using the BLAST search tool (Altschul and others, 1997). Clone library sequences were classified using the RDP Naïve Bayesian rRNA Classifier Version 2.0 (Wang and others, 2007).

Accession numbers: HM439882-HM439950; HQ144215-HQ144221.

\section{RESULTS}

\section{Physical characteristics}

The basal ice environment along this section of the GIS margin is well described (Sugden and others, 1987; Knight, 1987, 1989, 1994, 1997; Knight and others, 1994, 2002; Waller and others, 2000; Adam and Knight, 2003). However, since the basal ice microbiology has not been examined in previous studies, the linkage between basal ice formation processes and basal ice microbial community structures has yet to be determined. An important step to achieve this knowledge is to provide detailed analyses of basal ice-facies environments in relation to subglacial microbial investigations.

In the Russell Glacier profile, the bulk mineral composition of the debris-containing samples (BI2a, BI2b, BI4 and BI5) was uniform and primarily constituted of plagioclase and amphibole (Table 1). This differs from previously presented results of two samples of banded ice and one sample of solid ice $(0.063-0.25 \mathrm{~mm}$ fraction), where the proportion of quartz constituted $40 \%$ and $60 \%$, respectively (Knight and others, 1994). The pyroxene-to-plagioclase ratio
(0.10-0.15) was low and indicated no sorting due to mineral-specific gravity variations. The lack of gravity sorting is in accordance with similar analyses of basal ice beneath Kuannersuit Glacier, Greenland (Yde and others, 2005). Abrasion at the glacier bed produced fine-grained glacier flour composed mainly of mica (Table 1). The highest proportion of mica was found in the solid ice facies, but additional sampling is needed to confirm whether this is a distinct feature.

Debris concentrations by mass $(<2 \mathrm{~mm}$ in diameter) and grain-size distributions are shown in Table 2. The highest debris concentrations were found in solid ice and the lowest banded ice facies. The grain size distributions show that clay-sized particles constituted only $4-6 \%$, whereas silt-tosand ratios were $52-114 \%$ by mass. There were no indications of sorting due to grain size on a profile scale, but sorting may occur within debris bands.

The carbon content in basal ice derived primarily from organic carbon, whereas the proportion of carbon from carbonate minerals was within the analytical detection limit (Table 3). The sulfur content in the debris bands was small and within the analytical detection limit. In contrast, the solid ice facies contained a significant proportion of both organic and pyritic sulfur. These findings indicate that, despite centuries of glacier cover, the solid ice facies contains some organic carbon and sulfur that may be a potential energy source for heterotrophic as well as lithotrophic microorganisms. Carbonate minerals (e.g. disseminated calcite) may serve as a carbon source for autolithotrophic microbes in this environment. Pyrite is widely distributed in all debris-rich facies and may serve as a microbial sulfur source. The Mössbauer spectroscopic analysis of the solid ice facies showed that, in addition to pyrite, $\mathrm{Fe}^{2+}$-containing pyroxene and garnet are present and

Table 2. Debris concentration by mass (\%) and grain-size distribution $(<2 \mathrm{~mm}$ in diameter) by mass $(\%)$ in basal ice profile at the GIS margin

\begin{tabular}{lcccc}
\hline & Debris conc. & Sand & Silt & Clay \\
\hline BI2a Banded ice & 53.6 & 63.3 & 32.9 & 3.8 \\
BI2b Banded ice & 46.0 & 53.4 & 41.1 & 5.6 \\
BI4 Banded ice & 56.5 & 44.1 & 50.5 & 5.4 \\
BI5 Solid ice & 61.3 & 55.7 & 39.4 & 4.9 \\
\hline
\end{tabular}



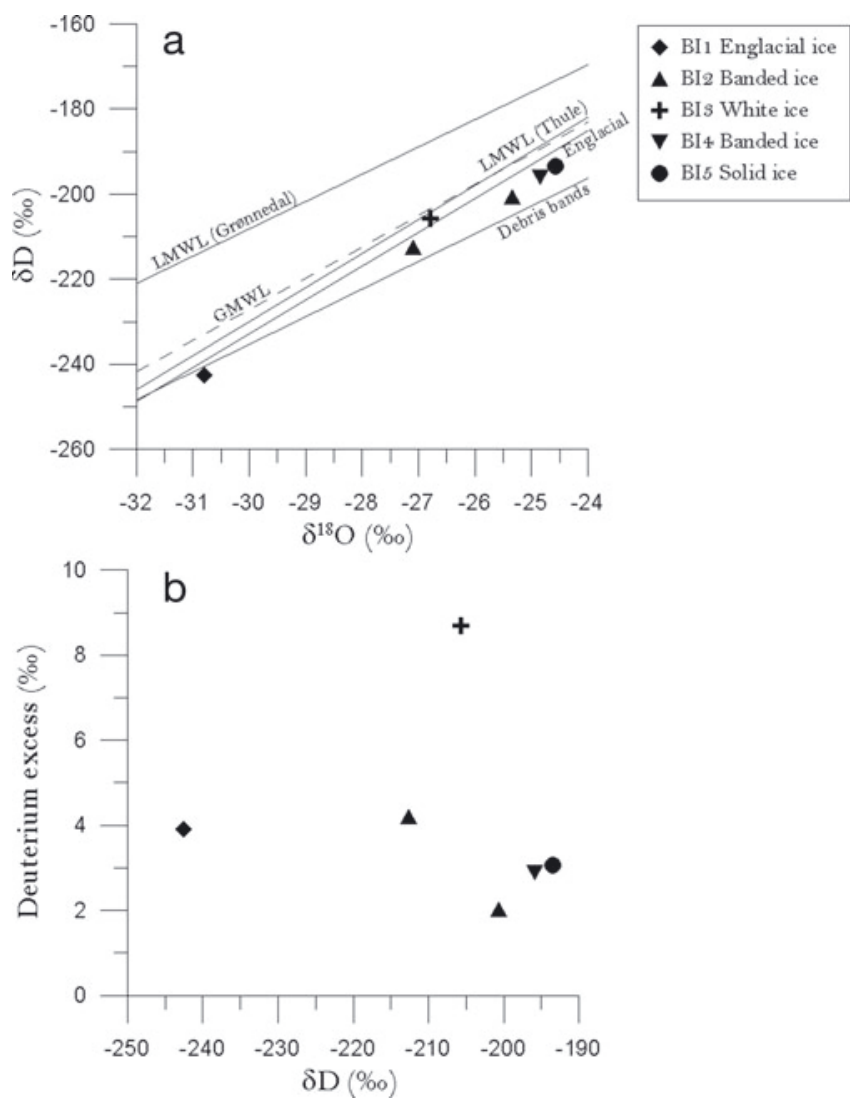

Fig. 3. (a) $\delta \mathrm{D}-\delta^{18} \mathrm{O}$ diagram showing the isotopic composition of basal ice facies in relation to the global meteoric waterline (GMWL), the local meteoric waterlines (LMWL) in Grønnedal and Thule (IAEA/WMO, http://www.iaea.org/water), and the englacial and debris band lines at Russell Glacier (Knight, 1989). (b) Deuterium-excess- $\delta \mathrm{D}$ diagram of basal ice facies.

also Fe-containing serpentinite, magnetite and hematite. Thus, Fe with various oxidation states is available from at least six different authigenic minerals. Few bioavailable Fe nanoparticulates were detected in the solid ice facies $(0.032 \% \mathrm{FeA})$. This is similar to previous findings from glaciers (Raiswell and others, 2008a) and less than in nearby turbid glacier meltwater $(0.049 \% F e A ; 0.197 \%$ FeD).

Stable water co-isotope analysis is a powerful tool to assess basal ice formation processes. The $\delta^{18} \mathrm{O}$ values in the basal ice facies ranged between $-24.6 \%$ and $-27.1 \%$, whereas the englacial ice facies had a lower ${ }^{18} \mathrm{O}$ content (Table 4). This trend is in accordance with a previous study of basal ice isotopic fractionation at Russell Glacier (Knight, 1989). Figure 3 shows a co-isotope diagram, where basal ice samples are plotted together with the global meteoric waterline (GMWL), two local Greenlandic waterlines (LMWL; data from International Atomic Energy Agency (IAEA)/World Meteorological Agency (WMO), http:// www.iaea.org/water), an englacial line from Russell Glacier (Knight, 1989) and a line based on five samples of debris-rich basal ice bands from Russell Glacier (Knight, 1989). If the white ice (BI3) is excluded, the slope of the remaining samples of 7.74 is close to the slope of the GMWL, the Thule $L M W L$ and the englacial ice. The isotopic distinction between englacial ice and debris bands found by Knight (1989) was not apparent in our profile. It is therefore not possible to determine the ice facies and subglacial isotopic fractionation solely by a co-isotope analysis. The white ice
Table 3. Carbon and sulfur composition of banded and solid ice facies in basal ice profile at the GIS margin. The proportions are expressed in \% by mass of the total debris content

\begin{tabular}{lcccc}
\hline & C organic & C carbonate & S organic & S pyrite \\
\hline BI2a Banded ice & 0.15 & 0.03 & 0.01 & - \\
BI2b Banded ice & 0.18 & 0.05 & 0.02 & 0.01 \\
BI4 Banded ice & 0.21 & 0.03 & 0.01 & 0.01 \\
BI5 Solid ice & 0.20 & 0.05 & 0.16 & 0.10 \\
\hline
\end{tabular}

(BI3) has a higher deuterium excess value than the other ice facies (Table 4; Fig. 3) and plots close to meteoric waterlines. The remaining samples have deuterium excess values between 2.0 and 4.2 and show no apparent correlation with $\delta \mathrm{D}$ (or $\delta^{18} \mathrm{O}$ ). This may indicate that the local meteoric water has an average deuterium excess value within this range, or that the basal ice facies composition is influenced by kinetic parameters (e.g. freezing rate, diffusion rate, boundary layer thickness) or by partial freezing of parent waters or nonequilibrium processes and variations in parent water.

\section{Microbiological investigations}

Oxygen consumption in the sediment was equally driven by biological and chemical oxygen consumption. Poisoning of subsamples with $\mathrm{ZnCl}_{2}$ indicated that chemical oxygen consumption accounted for $\sim 50 \%$ of the overall oxygen consumption, probably due to the re-oxidation of $\mathrm{Fe}^{2+}$ that was present in high concentration (Table 5). All the added ${ }^{15} \mathrm{~N}-\mathrm{NO}_{3}{ }^{-}$was consumed within 28 hours of incubation and transformed into ${ }^{30} \mathrm{~N}$-dinitrogen gas, thus indicating that nitrate reduction was primarily carried out by denitrifying bacteria. No signs of sulfate reduction were detected after 42 hours of incubation with ${ }^{35} \mathrm{~S}-\mathrm{SO}_{4}{ }^{2-}$.

The ability to digest different classes of organic compounds was evaluated with the EcoLog ${ }^{\mathrm{TM}}$ system. The following compounds were oxidized consistently (three out of three cases): the surfactant Tween 80, the polysaccharide $\alpha$-cyclodextrin, the di-saccharides D-cellobiose and $\alpha$-D-lactose, the sugars $\beta$-methyl-D-glucoside and Dxylose, the alcohol sugars $i$-erythritol and D-mannitol, the dicarboxylic acid itaconic acid, the amino acids L-arginine and L-asparagine and the dipeptide glycyl-L-glutamic acid. The oxidation of sugar glucose-1-phosphate was observed in two out of three cases, and oxidation of fatty acid $\gamma$-hydroxybuturic acid, amino-sugar $\mathrm{N}$-acetyl-D-glucosamine, amino acid L-threonine and amine phenylethylamine in one out of three cases.

Table 4. The $\delta^{18} \mathrm{O}, \delta \mathrm{D}$ and deuterium-excess characteristics (\%) in basal ice profile at the GIS margin

\begin{tabular}{llll}
\hline & $\delta^{18} \mathrm{O}$ & $\delta \mathrm{D}$ & Deuterium excess \\
\hline BI1 Englacial ice & -30.8 & -243 & 3.9 \\
BI2a Banded ice & -25.3 & -201 & 2.0 \\
BI2b Banded ice & -27.1 & -213 & 4.2 \\
BI3 White ice & -26.8 & -206 & 8.7 \\
BI4 Banded ice & -24.9 & -196 & 2.9 \\
BI5 Solid ice & -24.6 & -194 & 3.1 \\
\hline
\end{tabular}


Table 5. Bacterial abundance, oxygen consumption rates, nitrate reduction and sulfate reduction in solid basal ice at the GIS margin

\begin{tabular}{|c|c|c|c|c|}
\hline \multirow[t]{2}{*}{ Total cell numbers } & \multicolumn{2}{|c|}{ Oxygen consumption } & \multirow[t]{3}{*}{ Nitrate reduction } & \multirow[t]{3}{*}{ Sulfate reduction } \\
\hline & Total & Chemical & & \\
\hline cells $\mathrm{cm}^{-3}$ & $\mu \mathrm{Mcm} \min ^{-1}$ & $\mu \mathrm{Mcm} \min ^{-1}$ & & \\
\hline$\left(2.3 \times 10^{8}\right) \pm\left(7.6 \times 10^{7}\right)$ & $24.8 \pm 3.6$ & $11.6 \pm 1.8$ & $\begin{array}{l}100 \% \text { consumed within } 28 \text { hours } \\
\text { (denitrification) }\end{array}$ & $\begin{array}{c}\text { Not detected after } 42 \text { hours of } \\
\text { incubation }\end{array}$ \\
\hline
\end{tabular}

\section{Microbial diversity}

Pure cultures and enrichments were obtained both under aerobic and anaerobic conditions. On R2A plates, $\sim 20000$ colony-forming units (cfu) could be obtained from $1 \mathrm{~cm}^{3}$ of sediment. This is $\sim 0.1 \%$ of the total cell counts (Table 5 ). Most of the colonies had beige to white color and entire and smooth edges. No filamentous colonies or fungi were observed despite the absence of fungicide in the growth medium. Twenty colonies were selected for further investigations, of which nine currently have successfully been sequenced (Table 6). All nine colonies were most closely related to strains that inhabit glacial niches or permafrost. All isolates grew well at $4{ }^{\circ} \mathrm{C}$. In broth that stimulated growth of clostridia, $>10^{4}$ cells were counted upon serial dilution. A more precise estimate cannot be provided, since growth occurred in the highest inoculated dilution. The presence of spores, as was revealed by microscopic inspection, confirmed that clostridium-related microorganisms were present in the highest positive dilutions. Isolation of spore-formers has not been accomplished yet.

In total, 90 clones were sequenced, of which 70 provided high-quality sequences. The clone library was dominated by Proteobacteria sequences (37), of which 28 clustered with the $\beta$-subdivision, 7 with the $\alpha$-subdivision and 2 with the $\delta$ subdivision (Fig. 4). Of the $28 \beta$-proteobacteria, 12 were most closely related to members of the genus Rhodoferax in the order Burkholderiales, 6 could only be classified on the class level, while the remaining 10 grouped with other classified lineages of the $\beta$-subdivision. The second most abundant phylum was Bacteroidetes; of the 11 sequences, 6 fell into the order Sphingobacteriales, 1 into the order Bacteriodales and 1 into the order Flavobacteriodales. Three sequences that affiliated with the Bacteroidetes phylum remained unclassified. The third most abundant phylum was Firmicutis. Of the 7 sequences, 6 fell into the order Clostridiales and 1 into the order Bacillales. In addition, the following phyla were represented (number of sequences): Chloroflexi (1), Gemmatimonadetes (2), Acidobacteria (4), Actinobacteria (4) and Caldiserica (1). Three sequences could not be classified at the phylum level.

\section{DISCUSSION}

Since the sample that we investigated was frozen at the time of sampling but all investigations were carried out on thawed sediment, we cannot tell whether the microorganisms could have been active in the frozen state or were reactivated upon thawing. Metabolic activity down to $-40^{\circ} \mathrm{C}$ has been demonstrated by Panikov and others (2006), investigating the lower temperature limits of microbial permafrost communities. Similar observations have, however, not been reported yet from subglacial habitats.

The high concentration of $\mathrm{Fe}^{2+}$ in the solid ice facies indicates that oxygen was absent at the time of sampling and that solid ice thus provides an excellent niche for strict or facultative anaerobic microorganisms thriving either on fermentation or using alternative electron acceptors (e.g. nitrate, sulfate or iron oxides). This is also reflected by the outcome of both culture-dependent and -independent investigations, where we were able to culture both aerobic and anaerobic microorganisms. The latter are represented by the enrichment of spore-formers, most likely Clostridia, in high serial dilutions. We have also successfully enriched iron-reducers that are currently in the process of isolation (data not shown). The high denitrification potential supports the presence of a facultative anaerobic microbial community. Straub and others (1996) have demonstrated that denitrifiers thrive on the oxidation of ferrous iron when coupled to the reduction of nitrate, a process that may also take place in basal ice and subglacial sediments driven by high concentration of dissolved $\mathrm{Fe}^{2+}$. In contrast to what has been reported by Wadham and others (2004) from Finsterwalderbreen, Svalbard, sulfate reduction activity could not be detected in the solid ice facies even by the highly sensitive ${ }^{35} \mathrm{~S}_{-} \mathrm{SO}_{4}{ }^{2-}$ radiotracer method.

Total cell counts in the range of $10^{8}$ cells $\mathrm{cm}^{-3}$ sediment are comparable to numbers reported from Glacier de Tsanfleuron, Swiss Alps, (Sharp and other, 1999) and Midtre Lovénbreen, Svalbard (Reddy and others, 2009). The proportion of microorganisms that could be cultured on R2A medium under aerobic conditions represented only $0.1 \%$ of the total cell counts, which is at the low end of what has been

Table 6. Sequenced colonies in solid basal ice at the GIS margin and their nearest neighbours (GenBank)

\begin{tabular}{lccc}
\hline Isolate name & Nearest neighbour (GenBank accession No.) & Identity & \\
\hline BIS3BIS10 & Uncultured $\beta$-proteobacterium, Comamonadaceae (AY315174) & $99 \%$ & Franz Josef Glacier, New Zealand: glacier ice \\
BIS 4aBIS5BIS13 & Cultured Actinobacteria, Cellulomonas sp. (EF451634) & $99 \%$ & Svalbard: permafrost \\
BIS6 & Cultured Actinobacteria, Cellulomonas sp. (AF479365) & $99 \%$ & Glaciar Sajama, Bolivia: 12 000 year old glacier ice \\
BIS11 & Cultured Firmicutis, Paenibacillus sp. (FM955871) & $98 \%$ & Svalbard: permafrost \\
BIS14 & Actinobacteria, Cellulomonas sp. (FM955871) & $99 \%$ & Lovénbreen, Svalbard: glacial meltwater \\
BIS20 & Cultured $\beta$-proteobacterium, Polarmonas sp. (DO628934) & $99 \%$ & John Evans Glacier, Canada: subglacial sediment
\end{tabular}




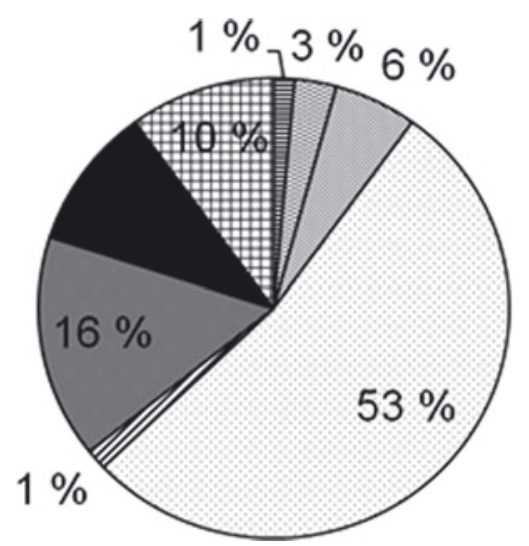

\begin{tabular}{|l|}
\hline 目Chloroflexi \\
$\square$ Gemmatimonadetes \\
$\square$ Acidobacteria \\
$\square$ Proteobacteria \\
$\square$ Caldiserica \\
$\square$ Bacteroidetes \\
$\square$ Fimicutes \\
⿴囗十 unclassified bacteria
\end{tabular}

Fig. 4. Distribution of cloned $16 \mathrm{~S}$ rRNA sequences from a basal-ice clone library (70 clones) within major bacterial phyla. The sequences were classified with the RDP classifier online tool.

reported in comparable studies (see review by Hodson and other, 2008). Although we have only sequenced a limited number of aerobic isolates so far, we find it interesting that all nine cultures had closest relatives among cultures that were retrieved from permanently cold habitats such as glacial ice or subglacial deposits (Foght and others, 2004; Skidmore and others, 2005) or permafrost (Hansen and others, 2007).

The origin of high concentrations of dissolved $\mathrm{Fe}^{2+}$ can derive from chemical and/or biologically mediated processes. The mineralogical composition of the bedrock that is rich in diverse iron minerals, as shown by Mössbauer spectroscopy, and contains authigenic Fe nanoparticulates allows $\mathrm{Fe}^{2+}$ release through chemical weathering and biological reduction. Support for the latter possibility is given by the composition of the microbial community revealed by cloning and sequencing and by the successful enrichment of iron reducers (data not shown). In particular, the abundance of Rhodoferax-related sequences is a good indication for an iron-reducing potential among the community members. Also the presence of a Geobacter-related sequence supports a microbial component in $\mathrm{Fe}^{2+}$ production. The predominance of Rhodoferax-related over Geobacter-related sequences may indicate that periods of oxia have taken place prior to the formation of the solid ice facies. In contrast to Geobacter strains, Rhodoferax strains are facultative anaerobes that thrive well with oxygen as electron acceptor. The abundance of Rhodoferax relatives in subglacial habitats has also been reported from Bench Glacier, Alaska, and John Evans Glacier, Canadian High Arctic, (Skidmore and others, 2005; Bhatia and others, 2006; Cheng and Foght, 2007) and recently from the West Antarctic ice sheet (Lanoil and others, 2009). Also, Tung and others (2006) reported on the presence of metabolically active iron reducers at the bottom of a GIS core (Greenland Ice Sheet Project 2 (GISP2)) that may be responsible for production of $\mathrm{Fe}^{2+}$ similar to what we observe.

In the Bench Glacier and John Evans Glacier studies, $\beta$ proteobacteria were most abundant and similar to this study, accounting for $>50 \%$ of the retrieved sequences. However, it has not yet been explained why this group, though cosmopolitan in subglacial habitats, is dominant. Since these studies are based on polymerase chain reaction (PCR) and cloning, both of which may introduce biases and therefore cannot be considered quantitative, it cannot yet be concluded that these observations reflect the real situation. This is also the case for the Bacteroidetes phylum. As in the other studies, the sequences in our study belonging to the phylum Bacteroidetes are the second most abundant. Also we cannot exclude that the dominance is due to bias. The dominance of Proteobacteria and Bacteroidetes was also found in a PCR- and cloning-independent study of a glacier ice metagenome (Simon and others, 2009), indicating that the dominance of both phyla in glacial habitats is likely to be real. Still, additional investigations using fluorescence in situ hybridization (FISH) or other quantitative methods are needed to determine the significance of the different phyla in the Russell Glacier solid ice facies. In addition to the sequences that affiliate with heterotrophic bacteria, we found several sequences that affiliate with the lithotrophic iron oxidizers within the genera Gallionella and Ferritrophicum, also members of the $\beta$-proteobacterium subdivision. In addition to iron oxidizers, we retrieved sequences closely related to the likewise lithotrophic but ammoniumoxidizing Nitrosospira group. These organisms, which are microaerophilic but obligate aerobes, depend on oxygen for their metabolism. Their presence may be taken as an indication for periodic oxygen intrusion.

The microbial community structure in basal ice facies is likely to be conditioned by basal ice formation processes such as regelation, basal freeze-on, thrusting, ice metamorphosis and apron overriding because these processes control mineral composition and grain size of entrained debris in various ways (e.g. Boulton, 1978) and thereby control potential energy sources for lithotrophic microorganisms. The solid ice facies differs from the overlying debris bands in having a relatively higher mica content, higher debris concentration and higher organic and pyritic sulfur content, indicating that solid ice facies is in a less weathered state than the debris bands. The lack of mineral and grain-size sorting effects indicates that the debris bands most likely formed by similar entrainment processes to the solid ice facies (Knight and others, 2002). This is supported by the coisotopic analysis, which shows no apparent differences between the solid ice facies and debris bands. Therefore, as there is little physical deviance between solid ice and debris bands, we hypothesize that the microbiological community found in solid ice is similar to what can be expected in debris-rich banded ice facies. In contrast, the co-isotopic analysis confirms that the white ice facies is meteoric in origin, and it is very likely to harbor a subglacial microbial ecosystem, which is different from the ecosystem found in solid ice facies. 
Overall our results confirm the new paradigm that subglacial environments, though dark and cold, are by no means deprived of life. We extend this observation to solid ice facies at the western margin of the GIS, which contains a large and diverse community of heterotrophic and lithotrophic microorganisms. However, their way of life needs to be revealed in order to understand their functioning in basal ice ecosystems and their interaction with the litho- and glaciospheres.

\section{CONCLUSIONS AND PERSPECTIVES}

Basal ice from the GIS margin contains a diverse population of both aerobic and anaerobic bacteria, thus confirming what has already been reported from glaciers worldwide but extending these observations to a hitherto microbiologically unexplored region. The dominance of the clone library by $\beta$ proteobacteria and Bacteroidetes adds to what has been reported from other glacier beds. This observation is still unexplained and awaits careful studies of isolates from these phyla to determine whether they have a specific genetic make-up that supports survival under these extreme conditions. These findings may even find interesting biotechnological applications.

We are very well aware of the limits of this study, since it deals with a single sample, taken at a single point in time. We hope, however, that it will attract the attention of other researchers in the field and that it will integrate into a long list of coordinated investigations of the microbiota, its diversity and activity beneath, within and on the surface of the GIS. In order to better assess microbiological deviations in basal ice and subglacial sediments and to determine potential linkages to distinct ice facies, more comprehensive surveys are needed in the Russell Glacier area and around the GIS. The latter would demand a coordinated approach by numerous research groups.

\section{ACKNOWLEDGEMENTS}

This study was funded by the Commission for Scientific Research in Greenland (KVUG; project No. 495229) and Carlsbergfondet. We thank T. Wiegers for valuable field and laboratory assistance. The Kangerlussuaq International Science Support (KISS) centre provided logistic assistance. This is publication No. A310 from the Bjerknes Centre for Climate Research.

\section{REFERENCES}

Adam, W.G. and P.G. Knight. 2003. Identification of basal layer debris in ice-marginal moraines, Russell Glacier, West Greenland. Quat. Sci. Rev., 22(14), 1407-1414.

Altschul, S.F. and 6 others. 1997. Gapped BLAST and PSI-BLAST: a new generation of protein database search programs. Nucleic Acids Res., 25(17), 3389-3402.

Bhatia, M., M. Sharp and J. Foght. 2006. Distinct bacterial communities exist beneath a High Arctic polythermal glacier. Appl. Environ. Microbiol., 72(9), 5838-5845.

Boulton, G.S. 1978. Boulder shapes and grain-size distributions of debris as indicators of transport paths through a glacier and till genesis. Sedimentology, 25(6), 773-799.

Bruun, A.-M., K. Finster, H.P. Gunnlaugsson, P. Nørnberg and M.W. Friedrich. 2010. A comprehensive investigation on iron cycling in a freshwater seep including microscopy, cultivation and molecular community analysis. Geomicrobiol. J., 27(1), 15-34.

Cappelen, J., ed. 2009. DMI daily climate data collection 18732008, Denmark, the Faroe Islands and Greenland, including air pressure observations 1874-2008 (WASA data sets). Copenhagen, Danish Meteorological Institute. (DMI Tech. Rep. 09-06.)

Cheng, S.M. and J.M. Foght. 2007. Cultivation-independent and -dependent characterization of Bacteria resident beneath John Evans Glacier. FEMS Microbiol. Ecol., 59(2), 318-330.

Escher, A., K. Sørensen and H.P. Zeck. 1976. Nagssugtoqidian mobile belt in West Greenland. In Escher, A. and W.S. Watt, eds. The geology of Greenland. Copenhagen, Geological Survey of Greenland, 77-95.

Foght, J. and 6 others. 2004. Culturable bacteria in subglacial sediments and ice from two Southern Hemisphere glaciers. Microbial Ecol., 47(4), 329-340.

Fossing, H. and B.B. Jørgensen. 1989. Measurement of bacterial sulfate reduction in sediments: evaluation of a single-step chromium reduction method. Biogeochemistry, 8(3), 205-208.

Greenwood, N.N. and T.C. Gibb. 1971. Mössbauer spectroscopy. London, Chapman \& Hall.

Hansen, A.A. and 7 others. 2007. Viability, diversity and composition of the bacterial community in a high Arctic permafrost soil from Spitsbergen, Northern Norway. Environ. Microbiol., 9(11), 2870-2884.

Hobbs, W.H. 1931. Reports of the Greenland expeditions of the University of Michigan (1926-1931). Ann Arbor, MI, University of Michigan Press.

Hodson, A. and 7 others. 2008. Glacial ecosystems. Ecol. Monogr., 78(1), 41-67.

Hubbard, B., S. Cook and H. Coulson. 2009. Basal ice facies: a review and unifying approach. Quat. Sci. Rev., 28(19-20), 1956-1969.

Knight, P.G. 1987. Observations at the edge of the Greenland ice sheet: boundary condition implications for modellers. IAHS Publ. 170 (Symposium at Vancouver 1987 - The Physical Basis of Ice Sheet Modelling), 359-366.

Knight, P.G. 1989. Stacking of basal debris layers without bulk freezing-on: isotopic evidence from West Greenland. J. Glaciol., 35(120), 214-216

Knight, P.G. 1994. Two-facies interpretation of the basal layer of the Greenland ice sheet contributes to a unified model of basal ice formation. Geology, 22(11), 971-974.

Knight, P.G. 1997. The basal ice layer of glaciers and ice sheets. Quat. Sci. Rev., 16(9), 975-993.

Knight, P.G., D.E. Sugden and C.D. Minty. 1994. Ice flow around large obstacles as indicated by basal ice exposed at the margin of the Greenland ice sheet. J. Glaciol., 40(135), 359-367.

Knight, P.G., R.I. Waller, C.J. Patterson, A.P. Jones and Z.P. Robinson. 2002. Discharge of debris from ice at the margin of the Greenland ice sheet. J. Glaciol., 48(161), 192-198.

Knight, P.G., C.E. Jennings, R.I. Waller and Z.P. Robinson. 2007. Changes in ice-margin processes and sediment routing during ice-sheet advance across a marginal moraine. Geogr. Ann., 89(3), 203-215.

Lanoil, B. and 7 others. 2009. Bacteria beneath the West Antarctic Ice Sheet. Environ. Microbiol., 11(3), 609-615.

Miteva, V.I., P.P. Sheridan and J.E. Brenchley. 2004. Phylogenetic and physiological diversity of microorganisms isolated from a deep Greenland glacier ice core. Appl. Environ. Microbiol., 70(1), 202-213.

Nielson, L.P. 1991. Denitrification in sediment determined from nitrogen isotope pairing. FEMS Microbiol. Lett., 86(4), 357-362.

Panikov, N.S., P.W. Flanagan, W.C. Oechel, M.A. Mastepanov and T.R. Christensen. 2006. Microbial activity in soils frozen to below $-39{ }^{\circ} \mathrm{C}$. Soil Biol. Biochem., 38(4), 785-794.

Raiswell, R., L.G. Benning, M. Tranter and S. Tulaczyk. 2008a. Bioavailable iron in the Southern Ocean: the significance of the iceberg conveyor belt. Geochem. Trans., 9(7). (10.1186/14674866-9-7.)

Raiswell, R., L.G. Benning, L. Davidson and M. Tranter. 2008b. Nanoparticulate bioavailable iron minerals in icebergs and glaciers. Mineral. Mag., 72(1), 345-348. 
Raiswell, R., L.G. Benning, L. Davidson, M. Tranter and S. Tulaczyk. 2009. Schwertmannite in wet, acid, and oxic microenvironments beneath polar and polythermal glaciers. Geology, 37(5), 431-434.

Reddy, P.V.V. and 8 others. 2009. Bacterial diversity and bioprospecting for cold-active enzymes from culturable bacteria associated with sediment from a melt water stream of Midtre Lovénbreen glacier, an Arctic glacier. Res. Microbiol., 160(8), 538-546.

Revsbech, N.P. and B.B. Jørgensen. 1986. Microelectrodes: their use in microbial ecology. In Marshall, K.C., ed. Advances in microbial ecology, Vol. 9. New York, etc., Plenum Publishing, 293-352.

Sharp, M., J. Parkes, B. Cragg, I.J. Fairchild, H. Lamb and M. Tranter. 1999. Widespread bacterial populations at glacier beds and their relationship to rock weathering and carbon cycling. Geology, 27(2), 107-110.

Sheridan, P.P., V.I. Miteva and J.E. Brenchley. 2003. Phylogenetic analysis of anaerobic material psychophilic enrichment cultures obtained from a Greenland glacier ice core. Appl. Environ. Microbiol., 69(4), 2153-2160.

Simon, C., A. Wiezer, A.W. Strittmatter and R. Daniel. 2009. Phylogenetic diversity and metabolic potential revealed in a glacier ice metagenome. Appl. Environ. Microbiol., 75(23), 7519-7526.

Skidmore, M.L., J.M. Foght and M.J. Sharp. 2000. Microbial life beneath a high Arctic glacier. Appl. Environ. Microbiol., 66(8), 3214-3220.

Skidmore, M., S.P. Anderson, M. Sharp, J. Foght and B.D. Lanoil. 2005. Comparison of microbial community compositions of two subglacial environments reveals a possible role for microbes in chemical weathering processes. Appl. Environ. Microbiol., 71(11), 6986-6997.

Stevens, J.G., A.M. Khasanov, J.W. Miller, H. Pollak and Z. Li, eds. 1998. Mössbauer mineral handbook. Asheville, NC, University of North Carolina. Mössbauer Effect Data Center.
Stookey, L.L. 1970. Ferrozine: a new spectrophotometric reagent for iron. Anal. Chem., 42(7), 779-781.

Straub, K.L., M. Benz, B. Schink and F. Widdel. 1996. Anaerobic, nitrate-dependent microbial oxidation of ferrous iron. Appl. Environ. Microbiol., 62(4), 1458-1460.

Sugden, D.E. and 6 others. 1987. Evidence for two zones of debris entrainment beneath the Greenland ice sheet. Nature, 328(6127), 238-241.

Tranter, M., M.J. Sharp, H.R. Lamb, G.H. Brown, B.P. Hubbard and I.C. Willis. 2002. Geochemical weathering at the bed of Haut Glacier d'Arolla, Switzerland - a new model. Hydrol. Process., 16(5), 959-993.

Tranter, M., M. Skidmore and J. Wadham. 2005. Hydrological controls on microbial communities in subglacial environments. Hydrol. Process., 19(4), 995-998.

Tung, H.C., P.B. Price, N.E. Bramall and G. Vrdoljak. 2006. Microorganisms metabolizing on clay grains in $3-\mathrm{km}$-deep Greenland basal ice. Astrobiology, 6(1), 69-86.

Wadham, J.L., S. Bottrell, M. Tranter and R. Raiswell. 2004. Stable isotope evidence for microbial sulphate reduction at the bed of a polythermal high Arctic glacier. Earth Planet. Sci. Lett., 219(3-4), 341-355.

Waller, R.I., J.K. Hart and P.G. Knight. 2000. The influence of tectonic deformation on facies variability in stratified debris-rich basal ice. Quat. Sci. Rev., 19(8), 775-786.

Wang, Q., G.M. Garrity, J.M. Tiedje and J.R. Cole. 2007. Naïve Bayesian classifier for rapid assignment of rRNA sequences into the new bacterial taxonomy. Appl. Environ. Microbiol., 73(16), $5261-5267$

Yde, J.C. and 6 others. 2005. The presence of thrust-block naled after a major surge event: Kuannersuit Glacier, West Greenland. Ann. Glaciol., 42, 145-150.

Yung, P.T., H.S. Shafaat, S.A. Connon and A. Ponce. 2007. Quantification of viable endospores from a Greenland ice core. FEMS Microbiol. Ecol., 59(2), 300-306. 